\title{
My City Illusion
}

\section{Shen Xingzhou}

LASALLE College of the Arts, Singapore

My name is Shen Xingzhou 沈行舟.

If you know Chinese, you can probably conjecture from the characters of my name my personality, and further still, my fate.

I was never a fatalist. I didn't believe that I would live my life by what the characters of my name determined.

I was born on February 12 1991.

That winter, when the first snowflake touched the ground, I was already 18 years old. Ever since, I have been away from my family, away from the place where I was born and raised.

The first four years in the new city, I was thrilled by the unprecedented freedom. I never slept. The night enticed me to the riverside, lured me by her majestic oriental pearl, lead me to cross the city of the modern multifarious crystal, placed me at a rain-swept flagstone alley where a long redolent melody coming from an old gramophone, wandered and lingered, smelling like yesterday's dream. And there a wild cat, eyes blazing, jumped from the night sky, tiptoed, and snuck into an antique shop.

Sleep was never essential. All I had was the night. But the night was ephemeral. So I indulged, luxuriated in what the night gifted until one day I realized I could no longer walk further along the aged flagstone road.

So I left.

The next city has no river, but a sea. It has shrunk half the size of the precious pearl city, but multipled ten fold in quantities of concrete, bricks. It has clusters of glass skyscrapers in front but shabby high buildings behind.

The local people speak some language I don't understand. But they explained to me in my mother tongue that the city has never slept. 
I hasten my footsteps to join them to see the streets with neon lights, and the burning Ferris wheel shining over the dark sea.

There I hesitated.

I heard the blemished star upon the night curtain say: "The light, so bright, so disturbing."

And I looked around; people had already become used to running into each other under the streetlights.

There I panicked.

But just at that moment, among the crowd, someone picked me up. Someone who doesn't speak my mother tongue; doesn't speak the local language.

He took me to the edge of the city.

On the way to his house there stood only one yellow dim streetlight.

I saw my shadow had lost its weight; fell on the ground. It was left behind me, and gradually slipped away. On the night breeze, new shadows came, on my face, on my shoulder, on my ankle. I saw myself slowly melting into the hug of the darkness.

From now on, being protected. No more exposure to the light, no more exposure to the crowd. Only the darkness, my darkness.

I assumed he must come from the depth of the ocean, his smile, like the soundless waves, and I drifted among his smile, never needing to pity the night, never pity the evanescence of the night.

I fell asleep in his darkish smile, my sleep lasted for another four years.

One typhoon night, the wind took away the silence, brought turbulence in its wake. It enveloped me like a huge airplane hovering low, ready to crash; like an old dog's deep moan, ready to attack.

I heard the fallen leaves crunching, the wooden floors creaking, I stepped out of the house.

It's late autumn already. The chill air sought my bare skin, awoke every cell inside my body. 
All of the sudden, I thought about the faraway, the place I came from, the place would soon welcome the winter, and soon, the snowflakes would be dressing the frozen lake. During that time there would be no birds in flight over the hills; there would be no footprint in sight. In each household, everybody, would gather together.

I told myself: "when the second snowflake touches the ground, I will be on my way home."

So I waited, waited, waited. The temperature dropped. Waited. The winter arrived, but still there was no trace of snow.

"Where's the snow?" I asked myself.

That night, I had a dream. I dreamt there was a snowing fish tank. I was captured inside. They told me there would be a show, there would be an audience, and they would put me in an armed suit, throw me into the fish tank, where I would have to fight against a beast till the moment of death. But I would not really die; I would come back to life, but come back to life there inside the fish tank where it always snows, and I would forever encounter the beast. In the backstage, I was getting suited up, one peek at the audience seats; I saw my family. They had no clue that they would witness my death thousands of times. Now, till my death, three hours remained.

Three hours later, I woke up in a white world. Silence took me in. The rays of the sun stood still in straight lines on the wall next to me. I pulled myself out off bed, came to the window. Outside the buildings reflected the whiteness directly onto my face; I could barely open my eyes.

Was it snow? I asked myself.

No it wasn't snow.

It was my next city.

I saw cars in lines driving along the highway, under the sun, looking ghastly pale, going far, faraway.

I had told myself, when the second snowflake touched the ground, I would be on my way home.

However, my next city has neither snow or winter.

I was born on Feb $12^{\text {th }}, 1991$, in a city of China named Hangzhou, when I was 18 years 
old, I moved to Shanghai, four years later I moved to Hong Kong and stayed for another four years, now I'm in Singapore.

My name is Shen Xingzhou. 沈行舟

Shen: on the left side of the Chinese character, the three drops, mean water.

My hometown Hangzhou owns the world famous West Lake, Shanghai has its Huangpu River, Hong Kong and Singapore, are both islands surrounded by sea.

Xing: means walk.

Zhou: is a boat.

Walk and boat, both are ways of transportation.

Xing and Zhou, together, in Chinese imply: to sail against the current, not to advance is to drop back.

Therefore, I have no reason to stop, and I will always be on the road. 